\title{
Waarom sommigen liever leraar worden en anderen beter geen bankier kunnen worden
}

Citation for published version (APA):

Dohmen, T. J. (2010). Waarom sommigen liever leraar worden en anderen beter geen bankier kunnen worden. Maastricht University. https://doi.org/10.26481/spe.20100319td

Document status and date:

Published: 19/03/2010

DOI:

$10.26481 /$ spe.20100319td

Document Version:

Publisher's PDF, also known as Version of record

\section{Please check the document version of this publication:}

- A submitted manuscript is the version of the article upon submission and before peer-review. There can be important differences between the submitted version and the official published version of record.

People interested in the research are advised to contact the author for the final version of the publication, or visit the DOI to the publisher's website.

- The final author version and the galley proof are versions of the publication after peer review.

- The final published version features the final layout of the paper including the volume, issue and page numbers.

Link to publication

\footnotetext{
General rights rights.

- You may freely distribute the URL identifying the publication in the public portal. please follow below link for the End User Agreement:

www.umlib.nl/taverne-license

Take down policy

If you believe that this document breaches copyright please contact us at:

repository@maastrichtuniversity.nl

providing details and we will investigate your claim.
}

Copyright and moral rights for the publications made accessible in the public portal are retained by the authors and/or other copyright owners and it is a condition of accessing publications that users recognise and abide by the legal requirements associated with these

- Users may download and print one copy of any publication from the public portal for the purpose of private study or research.

- You may not further distribute the material or use it for any profit-making activity or commercial gain

If the publication is distributed under the terms of Article $25 \mathrm{fa}$ of the Dutch Copyright Act, indicated by the "Taverne" license above, 


\section{Maastricht University}

\section{Dr. Thomas J. Dohmen}

School of Business and Economics

Waarom sommigen liever leraar worden en anderen beter geen bankier kunnen worden 
Waarom sommigen liever leraar worden en anderen beter geen bankier kunnen worden 


\section{Colofon}

Ontwerp en print: Océ Business Services, Maastricht

ISBN: 978-90-5681-329-1

NUR: 781

Alle rechten voorbehouden. Niets uit deze uitgave mag worden verveelvoudigd, opgeslagen in een geautomatiseerd gegevensbestand of openbaar gemaakt worden, zonder voorafgaande schriftelijke toestemming van de auteur of uitgever. 


\section{Waarom sommigen liever leraar worden en anderen beter geen bankier kunnen worden}

Rede uitgesproken bij de aanvaarding van het ambt van hoogleraar Onderwijs en Arbeidsmarkt aan de School of Business and Economics van de Universiteit Maastricht

Maastricht, 19 maart 2010

Door Dr. Thomas J. Dohmen 
Mijnheer de Rector Magnificus,

Waarde collega's, lieve familieleden en vrienden,

Zeer gewaardeerde toehoorders,

\section{Inleiding}

Mensen verschillen in veel opzichten. Ze verschillen in de capaciteiten waarover ze beschikken, de vaardigheden die ze hebben, de middelen die ze tot hun beschikking hebben en voorkeuren over wat ze aantrekkelijk vinden en wat niet. Deze bronnen van heterogeniteit leiden tot grote gedragsverschillen in allerlei domeinen van het leven. Het verklaren van deze heterogeniteit is de belangrijkste drijfveer voor mijn onderzoek als econoom. Economen proberen gedrag te verklaren vanuit de veronderstelling dat mensen juist die keuzes maken die het beste zijn voor hen. Wat de beste keuze is, hangt af van de beschikbare middelen, de mogelijkheden die er onder bepaalde omstandigheden zijn, incentives, informatie en -zeer belangrijk ook - van hun voorkeuren.

Risicovoorkeuren, tijdsvoorkeuren en sociale voorkeuren, zoals vertrouwen en reciprociteit, beïnvloeden talloze keuzes en nemen daarom een centrale plek in binnen de economische theorie. Risicovoorkeuren zijn belangrijkomdatbijnaelkeeconomischebeslissing een bepaaldemate van risico of onzekerheid met zich meebrengt. Tijdsvoorkeuren bepalen hoe afwegingen worden gemaakt tussen kosten en baten die op verschillende tijdstippen zichtbaar worden. Tijdsvoorkeuren beïnvloeden bijvoorbeeld het spaargedrag, investeringskeuzes, consumentenpatronen, maar ook iemands gezondheid, en zijn of haar geluksgevoel (Frederick, Loewenstein, and O'Donogue, 2002). Vertrouwen is belangrijk op het terrein van sociale interacties (Glaeser c.S., 2000; Kosfeld c.S., 2005). In veel interacties in het dagelijks leven zijn mensen afhankelijk van het gedrag van anderen. Dat maakt mensen kwetsbaar. Vertrouwen bepaalt daarom of iemand met anderen in bepaalde situaties al dan niet samenwerkt of deelneemt aan een sociale interactie. Wederzijds vertrouwen tussen partijen maakt de aantrekkelijkheid van handel veel groter, bijvoorbeeld door het reduceren van de contractkosten. Reciprociteit is een reactie in natura op vriendelijk of vijandig handelen. Conceptueel kan er een onderscheid gemaakt worden tussen positieve reciprociteit, de mate waarin mensen goed gedrag van anderen jegens hen belonen, en negatieve reciprociteit, de mate waarin mensen onaardig gedrag bestraffen. Mijn Maastrichtse collega professor Riedl heeft aangetoond dat reciprociteit de arbeidsmarktuitkomsten beïnvloedt en de prestaties op verschillende terreinen van 
het economische leven versterkt, doordat deze een rol speelt bij de manier waarop mensen er voor zorgen dat anderen hun verplichtingen nakomen (Fehr, Kirchsteiger and Riedl, 1993; Brown, Falk and Fehr, 2004).

De maatschappij en bedrijven proberen ook het gedrag van mensen te beïnvloeden door het geven van incentives: beloningen en straffen. Door financiële beloningen, waardering, belangstelling en aandacht van de baas en collega's afhankelijk te maken van resultaten en gedrag worden de keuzes van mensen gevormd. Dit noem ik een incentive-structuur.

In deze oratie laat ik zien dat mensen, op basis van hun economische kernvoorkeuren, zichzelf sorteren. Ze selecteren een bepaalde incentivestructuur, bijvoorbeeld door hun keuze voor een opleiding of beroep. Via incentive-structuren leidt heterogeniteit in voorkeuren dus tot waarneembare verschillen tussen mensen. Ze beïnvloeden onderwijs- en beroepskeuzes en daarmee vele arbeidsmarktuitkomsten. ${ }^{1} \mathrm{lk}$ zal u vandaag laten zien dat het belangrijk is om meer aandacht te schenken aan dit mechanisme. De relatie tussen voorkeuren en incentive-structuren biedt een nieuw perspectief waarmee wetenschappers belangrijke fenomenen in het onderwijs en op de arbeidsmarkt kunnen verklaren. ${ }^{2}$

Een voorbeeld is het loonverschil tussen vrouwen en mannen. Ook kan het ons helpen te verklaren waarom sommige mensen er de voorkeur aan geven om in de private sector te werken en anderen in de publieke sector. En, zoals u misschien al verwacht, kan zo ook gekeken worden naar de vraag waarom sommige mensen docent worden, terwijl anderen juist kiezen voor een ander beroep.

$1 \quad$ Er zijn andere zeer belangrijke wegen waarlangs voorkeuren arbeidsmarktuitkomsten beïnvloeden Zo toont de theorie van het menselijk kapitaal bijvoorbeeld aan dat iemands investeringen in hoger onderwijs afhankelijk zullen zijn van zijn of haar risico- en tijdsvoorkeuren (Becker, 1975; Ben-Porath, 1967; Levhari en Weiss, 1974; Mincer, 1958 en 1974). Hoewel er in de economische theorie stappen gezet zijn, is onze kennis van de impact van heterogeniteit in de voornaamste economische voorkeuren beperkt. Er zijn twee hoofdredenen die economen ervan hebben weerhouden om de implicaties van heterogeniteit in voorkeuren volledig te begrijpen. Ten eerste hebben economen veronderstellingen gemaakt over deze voorkeuren om hun modellen hanteerbaar en berekenbaar te houden. Zo wordt er vaak verondersteld dat voorkeuren homogeen zijn. Een klassieke veronderstelling postuleert een representatieve agent die risiconeutraal is, vooruit kijkt, consistent is in tijdsvoorkeuren en bovendien uit eigenbelang handelt. Ten tweede is het gedurende lange tijd moeilijk geweest om implicaties van heterogene voorkeuren te testen, omdat directe maatstaven voor voorkeuren doorgaans niet beschikbaar waren in sociaaleconomische databestanden.

2 Enkele empirische studies hebben de relatie tussen risicovoorkeuren en arbeidsmarktuitkomsten onderzocht. Bijvoorbeeld, DeLeire en Levy (2004) relateren beroepskeuzes aan verschillen tussen beroepen in het risico om een dodelijk ongeluk te krijgen, terwijl andere studies de bereidheid om risico's te nemen relateren aan de variantie in inkomen tussen beroepen (e.g., Bonin c.s., 2007; Guiso, Japelli en Pistaserri, 2002) of aan de beslissing om zelfstandige ondernemer te worden (e.g., Caliendo, Fossen en Kritikos, 2009; Cramer c.S., 2002; Ekelund c.S., 2005). In tegenstelling tot deze studies, wil ik in deze oratie graag de aandacht vestigen op een specifiek mechanisme dat een relatie ligt tussen de kerneconomische voorkeuren: namelijk de interactie tussen voorkeuren en incentive-structuren. 
Incentive-systemen kunnen worden benut om voor bepaalde banen de mensen aan te trekken die voor dat soort werk het meest geschikt zijn. Inzichten in dit mechanisme maken het mogelijk om economisch gedrag beter te voorspellen en kunnen daarom de beleidsvorming faciliteren. Zo kunnen we ons afvragen of wel de juiste mensen worden geselecteerd om leraar te worden, maar is vorig jaar ook duidelijk geworden dat de mensen die er de afgelopen decennia voor gekozen hebben in de financiële sector te gaan werken misschien niet de meest geschikte persoonlijkheden voor dit soort werk zijn. De relatie tussen voorkeuren en incentive-structuren kan echter ook verklaren waarom verandering heel moeilijk kan zijn.

Om te laten zien hoe voorkeuren bepalend zijn voor de beroepskeuze die mensen maken en welke consequenties dit heeft voor de maatschappij, ga ik vandaag in op risicovoorkeuren. Het moge duidelijk zijn dat risicovoorkeuren slechts één facet zijn van de voorkeuren en de persoonskenmerken die bepalen welke keuzes mensen maken. Aan de hand van de risicovoorkeur zal ik u een glimp laten zien van een veel algemener mechanisme. Ik nodig u uit om later vanavond en misschien zelfs aanstaand weekend, mee te denken over de implicaties van andere economische voorkeuren en persoonlijkheidskenmerken op de keuze en het gedrag van mensen. Ik ben ervan overtuigd dat $u$ tot interessante inzichten zult komen.

Om te laten zien hoe verschillen in voorkeuren keuzes en gedrag van mensen bepalen, is het van belang deze voorkeuren te meten in grote populaties. $3 \mathrm{lk}$ zal laten zien hoe risicovoorkeuren gemeten kunnen worden. Ik zal ingaan op de heterogeniteit in risicohouding en de factoren die deze heterogeniteit bepalen. Daarna zal ik uiteenzetten hoe risicovoorkeuren de keuze beïnvloeden om onder een bepaalde incentive-structuur te werken. Hierna zal ik aantonen hoe de interactie tussen risicovoorkeuren en incentive-structuren leidt tot bepaalde arbeidsmarktuitkomsten. Nadien zal ik nog een aantal beleidsimplicaties afleiden.

3 De laatste jaren is er vooruitgang geboekt in het meten van de economische kernvoorkeuren in grote representatieve steekproeven Maatstaven voor risicovoorkeuren (Dohmen c.s., 2010a), tijdsvoorkeuren (Andersen c.s., 2008), en sociale voorkeuren zoals vertrouwen (Dohmen c.s., 2008) en reciprociteit (Dohmen c.S., 2009) zijn ontwikkeld en geïntroduceerd in grootschalige enquêteonderzoeken zoals het Duitse sociaaleconomische panel onderzoek (SOEP). 


\section{Heterogeniteit in risicovoorkeuren}

Eerst dus het meten van risicovoorkeur. Omdat het gaat om de heterogeniteit moeten we risicovoorkeur meten in grote populaties. Dat is over het algemeen niet eenvoudig. Er komt een aantal problemen kijken bij het meten van voorkeuren. Veel van deze problemen zijn gerelateerd aan het meten op zich. In welke context moeten voorkeuren gemeten worden, voor welke factoren moet gecontroleerd worden en welke meetmethode moet er worden gebruikt? Andere problemen zijn meer conceptueel van aard. Dit soort problemen vloeit vaak voort uit de theoretische discussie: wat is de precieze definitie? Hoeveel parameters hebben we nodig om voorkeuren, bijvoorbeeld tijdsvoorkeuren, te bepalen? Kunnen we voorkeuren los van elkaar zien?

Het is geen verrassing dat het meten van risicovoorkeuren niet onomstreden is. Het is een feit dat er een omvangrijke literatuur bestaat over de concepten en de meetmethodes. Ik heb vandaag de tijd niet om op deze literatuur in te gaan. Belangrijk is echter dat economen over het algemeen risicovoorkeuren afleiden van de keuzes die mensen maken bij een loterij. Deze methode voor het blootleggen van risicovoorkeuren volgt direct uit de theorie van het verwachte nut (von Neumann and Morgenstern, 1944). Hoewel het raamwerk van het verwachte nut verre van onbetwist is, wordt het binnen de economie toch vaak gebruikt. 4 In het grootste deel van deze lezing richt ik mij op een enigszins onconventionele methode om risicovoorkeuren te meten, namelijk door mensen direct te vragen om een globale beoordeling te geven van hun bereidheid om risico's te nemen op een schaal van o tot 10 . De precieze formulering van deze algemene risicovraag is als volgt: "Hoe ziet u uzelf: bent u over het algemeen een persoon die volledig bereid is risico's te nemen of probeert u risico's te vermijden? Kruis alstublieft een vakje op de schaal aan, waarbij de waarde o betekent: 'helemaal niet bereid om risico's te nemen' en de waarde 10 betekent: 'heel erg bereid om risico's te nemen'." Deze matstaf is kwalitatief van aard en er is geen expliciete verwijzing naar een loterij. Opmerkelijk is dat desondanks deze aanpak zeer aantrekkelijk blijkt te zijn om een betrouwbare algemene maatstaf voor risicohouding in verschillende contexten af te leiden. Eerder onderzoek heeft laten zien dat deze maatstaf het risicogedrag in verschillende contexten voorspelt (e.g. Jaeger c.S., 2010).

4 Zie Starmer (2000) voor een overzichtsartikel over de ontwikkelingen in non-expected utility theory, dat de enorme vooruitgang reflecteert die is geboekt om bij besluitvorming onder onzekerheid. 
In een vergelijkende studie hebben we respondenten deze eenvoudige algemene risicovraag laten beantwoorden en een loterijvraag met echte beloningen voorgelegd. Het antwoord op de algemene risicovraag blijkt het gedrag in loterijkeuzes, waarin echte belangen op het spel staan, te voorspellen (Dohmen c.S., 2010).

Figuur 1 laat de verdeling zien van de algemene risicohouding voor een representatieve steekproef van 22.000 respondenten in Duitsland. Elke staaf in het diagram beschrijft de fractie mensen die een bepaald punt op de elfpunts-risicoschaal heeft gekozen. De figuur laat zien dat er sprake is van een substantiële heterogeniteit in de risicohouding in de populatie: de modale respons is 5, maar de bereidheid om risico's te nemen varieert behoorlijk over de gehele schaal. Een relatief kleine groep respondenten kiest de waarde 10, hetgeen aangeeft dat ze heel erg bereid zijn om risico's te nemen, terwijl een iets grotere groep van ongeveer 7 procent van alle mensen de waarde o kiest. Deze waarde geeft aan dat ze helemaal niet bereid zijn risico's te nemen.

\section{Figuur 1}

De verdeling van risicohouding in een representatieve steekproef onder volwassenen.

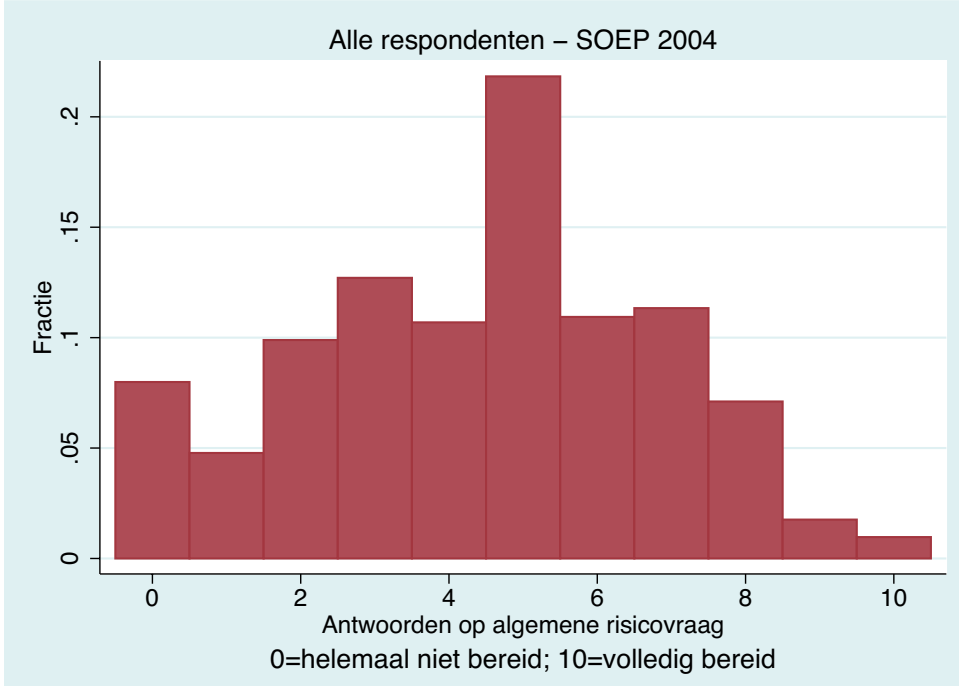

Noot: De figuur laat een histogram zien van de antwoorden op de vraag over de bereidheid tot het nemen van risico's in het algemeen, gemeten op een elfpunts-schaal.

Bron: Socio-Economische Panel Studie (SOEP), 2004. 


\section{Determinanten van risicovoorkeuren}

Een voor de hand liggende vraag is of de heterogeniteit in risicohouding gedeeltelijk systematisch is en daarmee leidt tot verschillen in economische beslissingen tussen verschillende groepen mensen.

Figuur 2 laat het verschil in risicohouding tussen vrouwen en mannen zien. ledere kleur geeft aan hoe groot het verschil is tussen de fractie vrouwen en de fractie mannen met een bepaalde waarde op de schaal voor risicohouding. Het is goed te zien dat vrouwen minder bereid zijn om risico's te nemen dan mannen. Relatief meer mannen dan vrouwen kiezen een hogere waarde op de risicoschaal. De figuur geeft daarmee een eerste indicatie dat vrouwen minder bereid zijn om risico's te nemen dan mannen.

\section{Figuur 2}

Verschillen tussen mannen en vrouwen in de bereidheid om risico's te nemen.

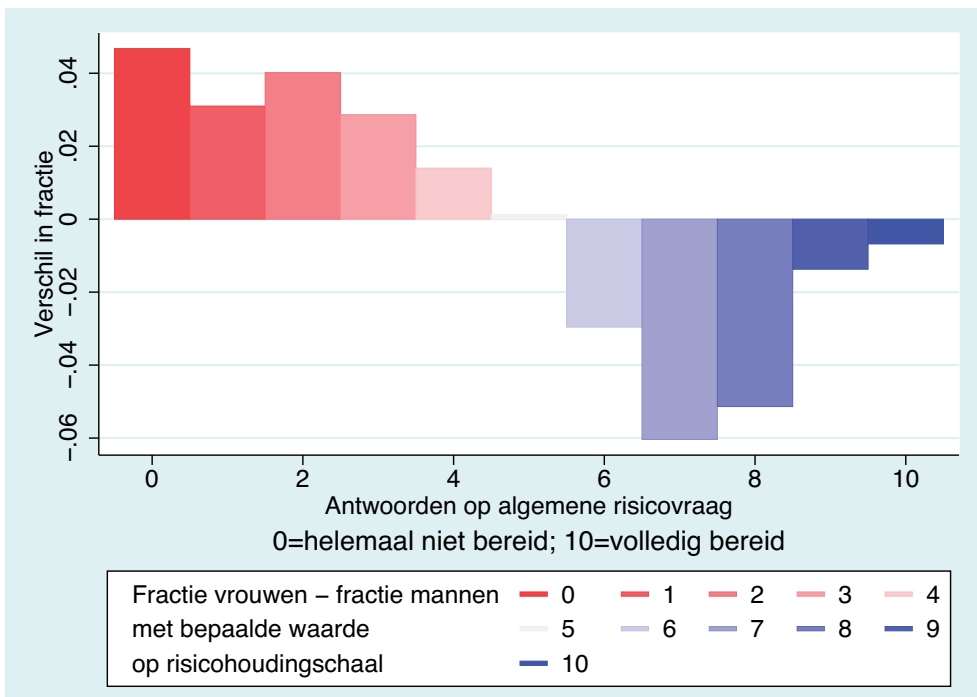

Noot: De figuur geeft het verschil weer tussen de fractie vrouwen en de fractie mannen die kiezen voor een bepaalde antwoordcategorie op de elfpunts-risicoschaal. Een positief verschil voor een gegeven categorie wil zeggen dat relatief meer vrouwen dan mannen voor die antwoordcategorie kiezen. Bron: SOEP, 2004. 
Figuur 3 geeft de relatie weer tussen de leeftijd en de risicohouding van mannen. Links staan de jongste mannen en rechts de oudste mannen. Voor elke leeftijd laten de rode staven de fractie antwoorden zien die in de eerste 5 antwoordcategorieën valt, terwijl de blauwe staven aangeven hoe groot het aandeel mannen is met een antwoord van 6 of hoger op de schaal. Een donkerdere tint staat voor een extremer antwoord. Uit de figuur blijkt duidelijk dat het percentage mannen dat minder graag risico's neemt, sterk toeneemt met de leeftijd.

\section{Figuur 3}

Risicohouding van mannen over de levensloop

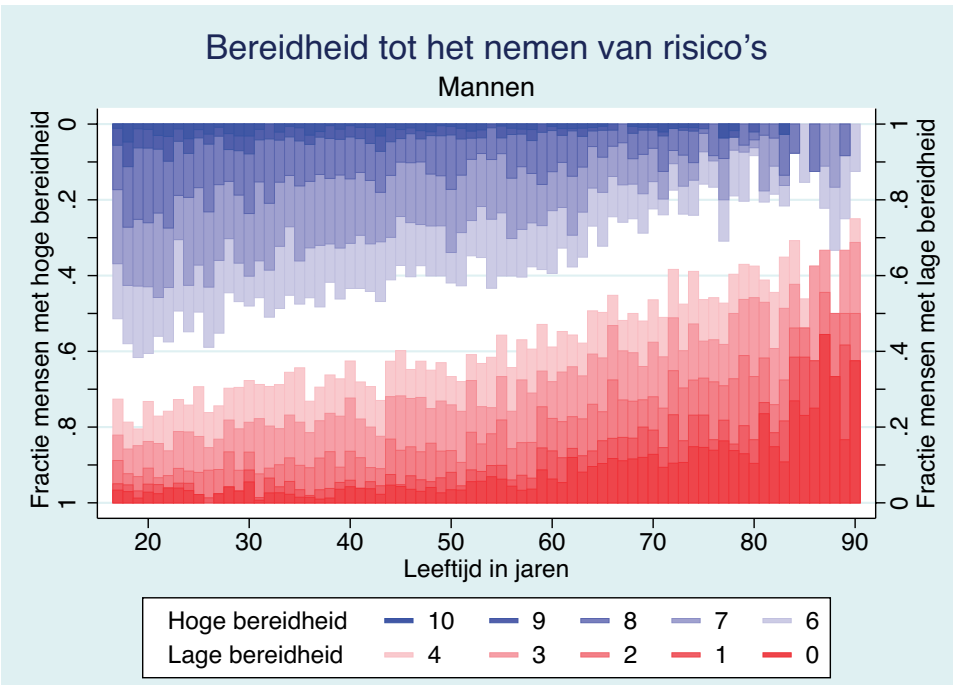

Noot: De gekleurde balken geven aan welk deel van de mannen met een bepaalde leeftijd kiest voor een specifieke waarde op de elfpunts-schaal bij de algemene risico vraag. De donkerste rode kleur geeft aan welk deel kiest voor o, i.e. "helemaal niet bereid om risico's te nemen". De lichtere rode kleuren komen overeen met de keuzemogelijkheden 1 tot 4 , terwijl het witte vlak de antwoordcategorie 5 weergeeft. De geleidelijk donker wordende blauwe vlakken boven het witte deel geven aan dat er wordt gekozen voor de waardes 6 tot en met 10 (de maximale waarde 10 geeft aan dat iemand "zeer bereid is om risico's te nemen"). Bron: SOEP, 2004.

Figuur 4 geeft hetzelfde beeld voor vrouwen. Ook vrouwen blijken minder bereid te zijn om risico's te nemen naarmate ze ouder zijn. Bovendien zien we hier opnieuw dat voor alle leeftijdscategorieën geldt dat vrouwen minder bereid zijn om risico's te nemen dan mannen. 


\section{Figuur 4}

Risicohouding van vrouwen over de levensloop

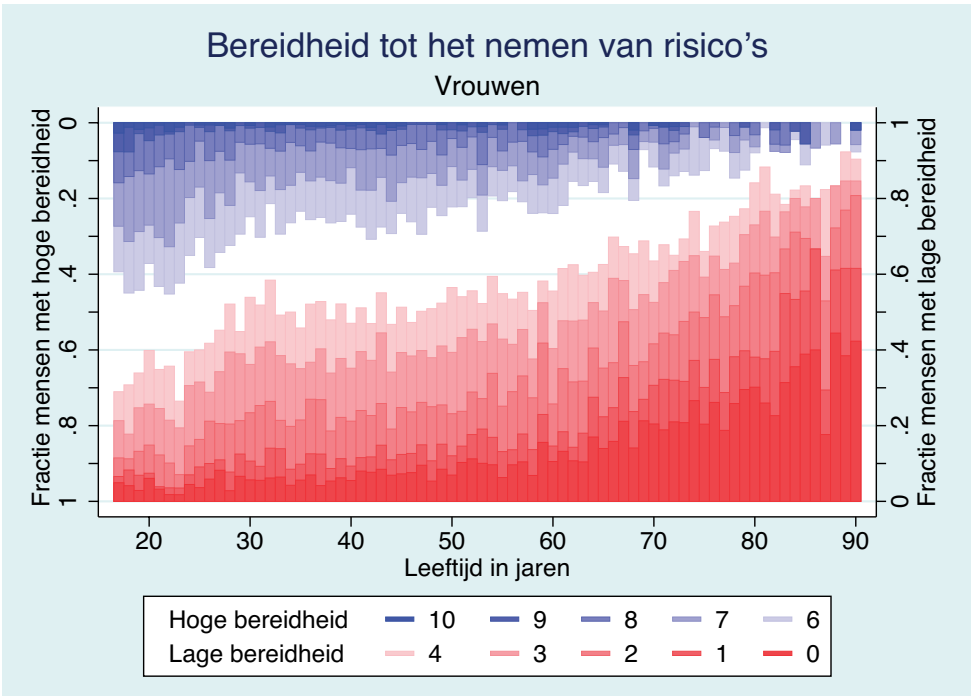

Noot: De gekleurde balken geven de fractie vrouwen met een bepaalde leeftijd aan, die kiest voor een specifieke waarde op de elfpunts-schaal bij de algemene risico vraag. De donkerste rode kleur geeft de fractie aan die kiest voor o, i.e. "helemaal niet bereid om risico's te nemen". De lichtere rode kleuren komen overeen met de keuzemogelijkheden 1 tot en met 4, terwijl de witte balk de keuze voor 5 weergeeft. De geleidelijk donker wordende blauwe balken boven het witte deel geven aan dat er wordt gekozen voor 6 tot en met 10 (de maximale waarde 10 geeft aan dat iemand "zeer bereid is om risico's te nemen"). Bron: SOEP, 2004.

Ook lengte, een eigenschap die direct beïnvloed is door iemands ouders, is gerelateerd aan zijn of haar risicovoorkeur. Dit geldt voor zowel mannen als vrouwen (zie figuur 5 en figuur 6). Voor beide geslachten geldt dat lange personen meer bereid zijn om risico's te nemen. 5

Ook als we controleren voor andere kenmerken van een persoon blijken geslacht, leeftijd en lengte significante voorspellers van risicohouding te $z_{i j n}{ }^{6}$ Ook de familieachtergrond speelt een rol bij de risicohouding.

5 De resultaten met betrekking tot determinanten zoals leeftijd, geslacht, inkomen, vermogen, en lengte worden eveneens gevonden voor een representatieve steekproef in de Oekraïne.

6 Zie tabel 1 in Dohmen c.s. (2010a). 
Zo zijn kinderen van hoogopgeleide ouders meer bereid om risico's te nemen dan kinderen van lageropgeleide ouders. Kinderen uit een meer welvarende omgeving zijn eveneens meer bereid risico's te nemen.

\section{Figuur 5}

Lengte en de risicohouding

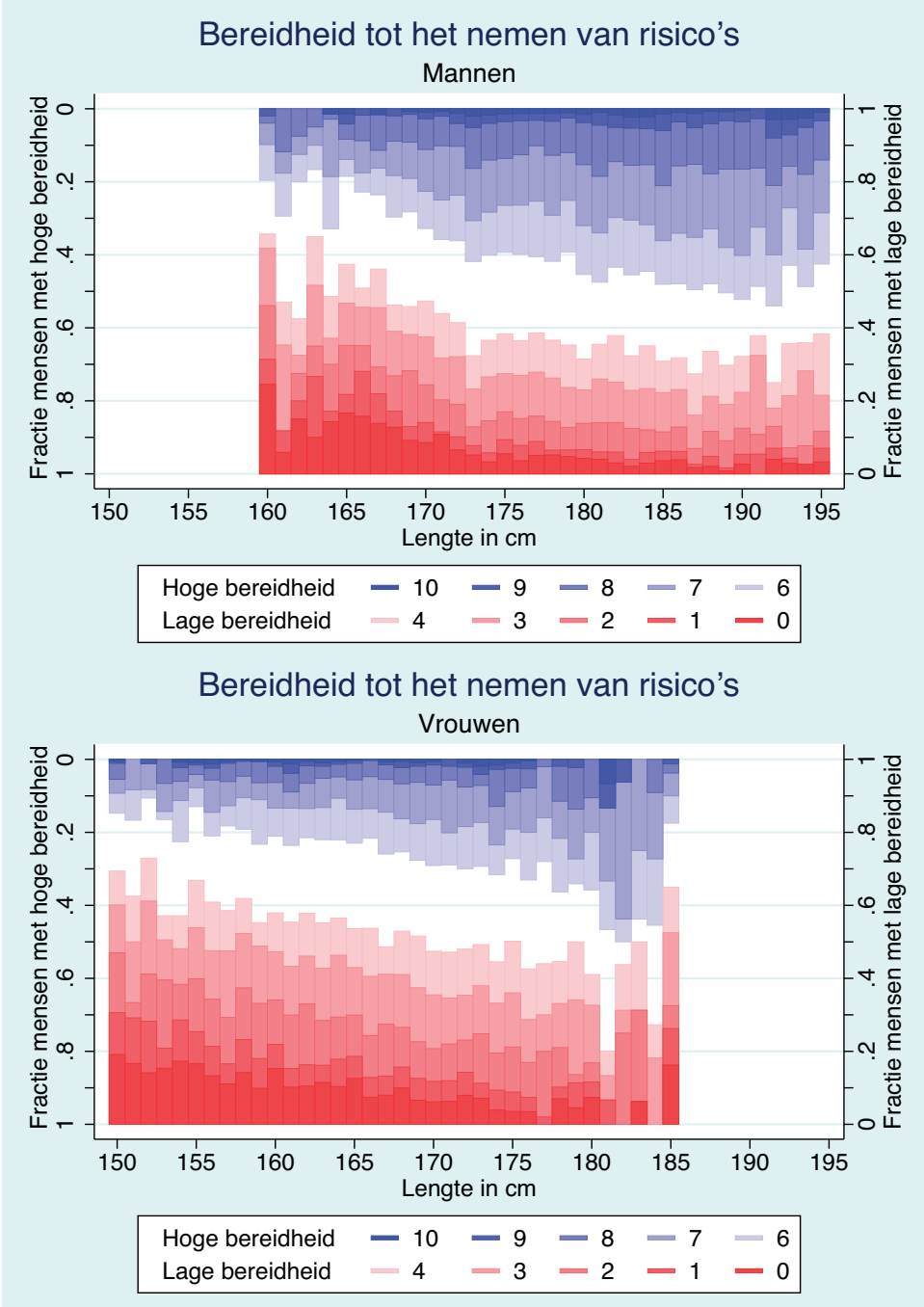


Noot: De gekleurde balken geven de fractie mannen (grafiek bovenaan) en vrouwen (grafiek onderaan) met een bepaalde lengte aan die kiest voor een specifieke waarde op de elfpunts-schaal bij de algemene risicovraag. De donkerste rode kleur geeft aan welk deel kiest voor o. De lichtere rode kleuren komen overeen met de keuzemogelijkheden 1 tot en met 4 , terwijl de witte balk de keuze voor 5 weergeeft. De geleidelijk donker wordende blauwe balken boven het witte deel geven aan dat er wordt gekozen voor 6 en hoger. Om problemen aangaande lage celvulling te voorkomen voegen we mannen die langer zijn dan $195 \mathrm{~cm}$ samen met degenen die $195 \mathrm{~cm}$ lang zijn (en vrouwen die langer zijn dan $185 \mathrm{~cm}$ met degenen die $185 \mathrm{~cm}$ lang zijn) alsook de mannen die kleiner zijn dan $160 \mathrm{~cm}$ samen met degenen die $160 \mathrm{~cm}$ lang zijn (en vrouwen die kleiner zijn dan $150 \mathrm{~cm}$ samen met degenen die $150 \mathrm{~cm}$ lang zijn). Bron: SOEP, 2004.

Daarnaast bestaat er een interessante correlatie tussen intelligentie en bereidheid tot het nemen van risico's (zie Dohmen c.S., 2010b). Dit laat figuur 6 zien.

\section{Figuur 6}

Intelligentie en risicohouding

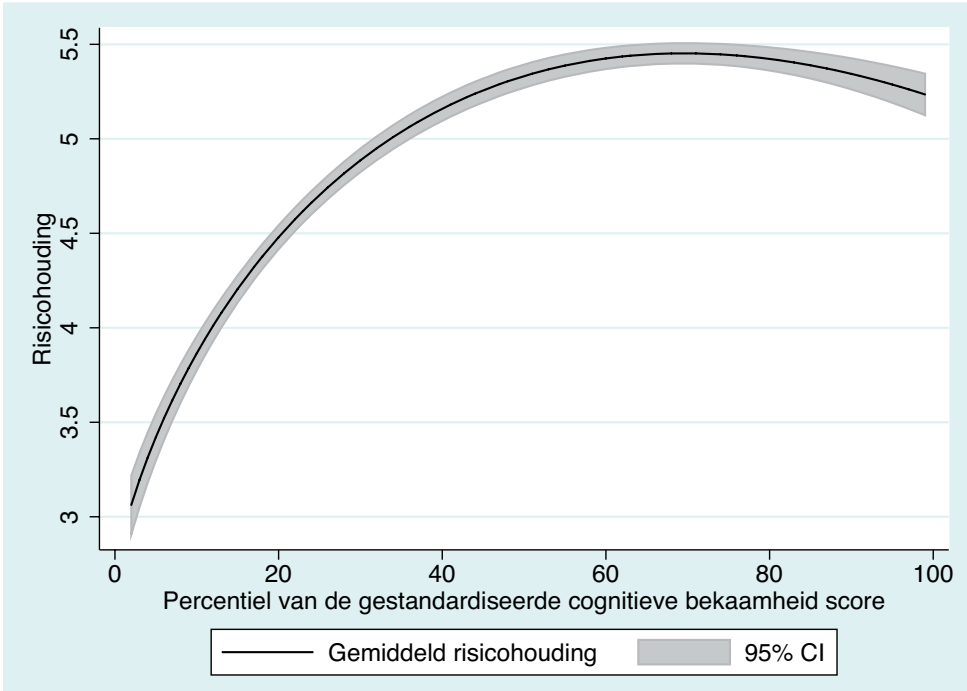

Noot: Diagram van fractionele polynomische voorspellingen. Cognitief vermogen wordt gemeten door middel van de gestandaardiseerde gemiddelde score op de gestandaardiseerde "symbol digit correspondence" en "word fluency" toetsen. Deze zijn ontleend aan de pretest van SOEP 2005 (zie Dohmen et al., 2010b). De bereidheid om risico's te nemen wordt gemeten aan de hand van de algemene risicovraag. Bron: SOEP pretest, 2005 . 
De relatie tussen risicohouding, intelligentie en lengte suggereert dat iemands voorkeuren gedeeltelijk worden gevormd tijdens de jeugd. Lange kinderen zijn fysiek vaak sterker dan andere kinderen en zouden daardoor later meer durven. Intelligente kinderen zouden meer zelfvertrouwen kunnen krijgen en om dezelfde redenen later meer bereid kunnen zijn om risico's te nemen. En omdat intelligentie en lengte, tot op zekere hoogte, genetisch overdraagbaar zijn van ouders op kinderen, kan dit ook betekenen dat de voorkeuren van ouders en kinderen ook aan elkaar gerelateerd zijn.

In een andere studie (Dohmen c.S., 2006) laten we inderdaad zien dat voorkeu ren worden overgedragen van de ene generatie op de andere. Figuur 7 illustreert dat kinderen over het algemeen meer bereid zijn risico's te nemen, wanneer hun vader of moeder ook meer bereid is om risico's te nemen. Dit verband wordt nog eens versterkt door de wijze waarop relaties tussen mannen en vrouwen gevormd worden. Mannen die van risico houden trouwen vrouwen die ook van risico houden. Doordat partners vaak vergelijkbaar zijn met betrekking tot hun economische kernvoorkeuren worden de verschillen tussen kinderen in onze samenleving uitvergroot.

\section{Figuur 7}

Overdraagbaarheid van risicohouding van de ene generatie op de volgende
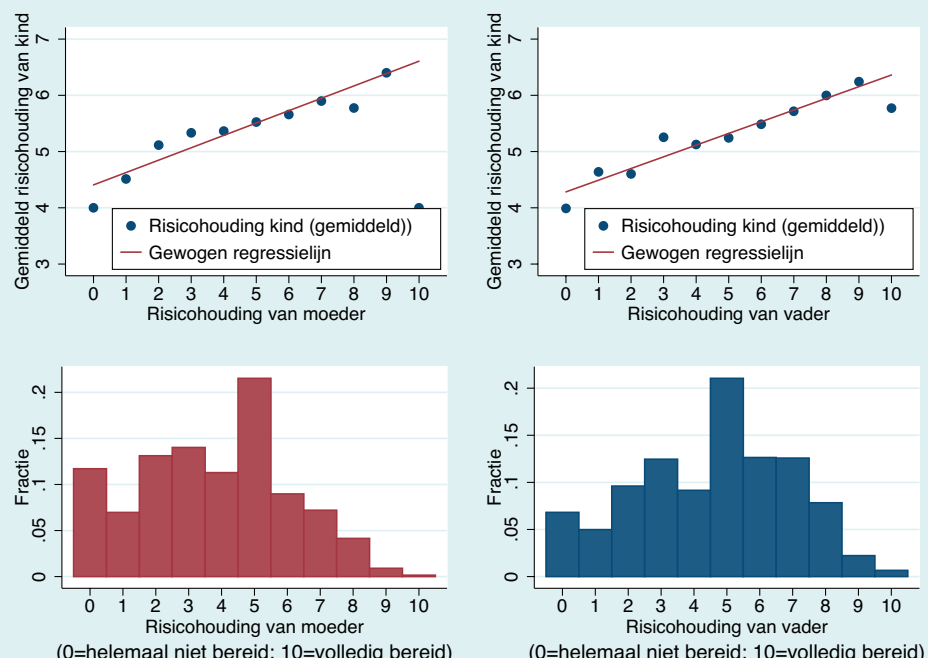

Noot: De bovenste figuren geven weer hoe kinderen hun eigen bereidheid tot het nemen van risico's beoordelen, bij een gegeven bereidheid tot het nemen van risico's van de moeder (linker 
diagram) en van de vader (rechter diagram). De histogrammen die er onder staan, geven de antwoorden op de algemene risicovraag weer van moeders (linker histogram) en vaders (rechter histogram).

Uit representatieve metingen van risicohouding komen dus vier hoofdbevindingen naar voren: Mensen verschillen met betrekking tot de voornaamste economische voorkeuren. Ten tweede zijn er belangrijke verschillen tussen de voorkeuren van mannen en vrouwen; voorkeuren veranderen op een systematische manier over de levensloop; en ten slotte zijn voorkeuren overdraagbaar van de ene generatie op de volgende.

Voordat ik inga op de implicaties van deze bevindingen voor de relatie tussen voorkeuren en incentive-systemen, ga ik eerst nog in op de selectieeffecten van incentive-structuren.

\section{Zelfselectie in incentive-structuren}

Met incentives proberen mensen het gedrag van anderen te beïnvloeden. De grondgedachte achter het aanbieden van incentives op het werk is het op één lijn brengen van de interesses van de werkgever en zijn medewerker. In de economie spreken we vaak van de principaal en de agent. Beloningsincentives die worden aangeboden om dit doel te bereiken komen meer en meer voor. Financiële prikkels om dit te bereiken zijn stukloon, bonusregelingen, winstdeling en carrièremogelijkheden die afhangen van eerdere prestaties. Uiteraard motiveren managers hun werknemers ook met secundaire arbeidsvoorwaarden, maar ook met belangstelling, aandacht en waardering. Dit zijn allemaal incentives.

Theoretisch en empirisch onderzoek heeft zich vooral gericht op het incentive-effect van dit soort variabele beloningsregelingen. Als mensen meer prikkels krijgen om betere prestaties te leveren, gaan zij ook betere prestaties leveren. Maar naast deze directe motiverende werking van incentives, hebben incentive-systemen ook een effect op zelfselectie. Professor Lazear (2000) laat zien dat productieve werknemers de voorkeur geven aan een bedrijf met stukloon in plaats van een bedrijf dat een vast loon biedt, simpelweg omdat deze productievere werknemers op basis van stukloon een hoger loon verwachten. Naast de verwachte beloning kunnen andere aspecten van de verschillende beloningssystemen eveneens een belangrijke rol spelen.

In dit geval voelen werknemers met verschillende voorkeuren en attitudes zich aangetrokken tot verschillende beloningsregelingen. Risicomijdende werknemers willen een vaste beloning. Risicozoekende werknemers willen kans maken op een bonus. Dit leidt tot een systematische 
zelfselectie in bepaalde bedrijven en organisaties. Indien werknemers zichzelf op basis van voorkeuren selecteren in bepaalde incentive-systemen dan hangt hun prestatie niet alleen af van de directe werking van de incentives, maar ook van dit selectie-effect.

Incentive-systemen bepalen dus niet alleen hoe productief de zittende werknemers zijn, maar ook welke type werknemer zich aangetrokken voelt tot dit bedrijf. De vraag is of dit de werknemers zijn waar dit bedrijf behoefte aan heeft. Voorkeuren en gedrag van werknemers beïnvloeden de manier waarop output wordt gegenereerd, de manier waarop collega's met elkaar samenwerken en de manier waarop klanten en cliënten worden benaderd. De samenstelling van het personeelsbestand is daardoor een belangrijke factor voor een productief bedrijf. Mensen met bepaalde voorkeursparameters kunnen daarom heel nuttig zijn voor het ene bedrijf maar contraproductief in een ander bedrijf.

Samen met mijn collega professor Armin Falk hebik deze mechanismes in een laboratoriumsetting getest (zie Dohmen en Falk, 2010a). Hier komt inderdaad naar voren dat variabele beloningsystemen de meest productieve personen aantrekken. Ten tweede is het percentage vrouwen dat een variabel beloningssysteem kiest altijd lager dan het percentage mannen, ongeacht of het stukloon, carrièremogelijkheden of winstdeling betreft. De risicohouding is ook van grote invloed op de keuze die deelnemers maken.

In ons experiment, is het geslachtsverschil in het kiezen van beloningssystemen grotendeels te verklaren door het verschil in risicohouding tussen mannen en vrouwen. Dit resultaat geeft al een indicatie dat manvrouw-verschillen in arbeidsmarktuitkomsten gedeeltelijk herleid kunnen worden tot man-vrouw-verschillen in de voornaamste economische voorkeuren.7

Het is belangrijk om te melden dat wij bovenop de selectiepatronen ook een direct incentive-effect vinden. Variabele beloningsregelingen leiden

Een ander interessant resultaat is dat de invloed van voorkeuren aan relevantie toeneemt naarmate werknemers dichter bij de drempel zijn waarvoor geldt dat het verwachte nut van werken voor een variabele beloning gelijk is aan dat van het werken voor een vaste beloning. De productiviteit van deze werknemers is doorgaans zodanig dat hun verwachte variabele inkomen min of meer gelijk is aan hun verwachte vaste inkomen. Deze individuen vinden het moeilijker om een beslissing te nemen en doen hier daarom langer over. We hebben de tijd bijgehouden die mensen nodig hadden om een selectiekeuze te maken. Voor mensen die langer deden om te beslissen dan de mediaan is risicohouding relatief veel belangrijker is dan productiviteit, omdat hun productiviteit geen duidelijke indicatie geeft voor de beloningsregeling die hun voorkeur heeft. Dit is een belangrijk resultaat, omdat productiviteitsverschillen in de werkelijke arbeidsmarkt doorgaans al worden bewerkstelligd door de banen die men heeft. Daardoor worden naast het daadwerkelijke beloningsniveau, de andere kenmerken van de beloningsregelingen, relatief belangrijker. Risicovoorkeuren worden ook kwantitatief belangrijker naarmate de inkomensonzekerheid bij de verschillende variabele beloningssystemen toeneemt. Voor meer details zie Dohmen en Falk (2010a). 
ook bij vergelijkbare personen tot een hogere productiviteit, maar ook tot meer stress en uitputting.

Als voorkeuren van invloed zijn op de keuze voor de verschillende incentive-systemen die bedrijven hanteren, dan is de samenstelling van het personeelbestand afhankelijk van deze zelfselectie van werknemers. In dit opzicht heeft het aanbieden van incentives binnen bedrijven en organisaties twee belangrijke effecten: een direct incentive-effect, en een selectie-effect. Bedrijven krijgen niet alleen meer output als ze daarvoor betalen, maar ook andere persoonlijkheden als ze ánders betalen. Dit heeft belangrijke consequenties voor bedrijven en werknemers. ${ }^{8}$

\section{Implicaties voor de arbeidsmarkt}

Nu zou ik graag wat bewijs vanuit de arbeidsmarkt aan u willen tonen en willen ingaan op enkele belangrijke beleidsimplicaties.

De publiekesectorkangrotendeelsgekarakteriseerd worden doorvaste Ionen en arbeidszekerheid. In de private sector komt prestatiebeloning vaker voor en is de kans groter om werkloos te worden. Op basis van de laboratoriumexperimenten kan verwacht worden dat werknemers in de publieke sector meer risicomijdend zijn en dat er meer vrouwen in de publieke sector werken. Tabel 1 laat zien dat dit in Duitsland inderdaad zo blijkt te zijn. De tabel geeft aan hoe groot de kans is dat iemand in de publieke sector werkt (zie kolom 1). Vrouwen hebben een hogere kans. Mensen die graag risico nemen hebben juist een kleinere kans. Een voor de hand liggende volgende vraag is of de risicohouding ook een rol speelt bij de selectie van typen werknemers binnen de private sector. De volgende kolommen (kolommen 2 en 3) laten zien dat respondenten vaker werkzaam zijn in een baan met prestatiebeloning, naarmate zij meer bereid zijn om risico's te nemen. Vrouwen hebben een kleinere kans op prestatiebeloning en hoogopgeleiden hebben een grotere kans op een baan met prestatiebeloning. 9

Vanuit het perspectief van het bedrijf hebben de resulterende selectiepatronen gevolgen voor de samenstelling van het personeelsbestand en voor de effectiviteit van de incentives. Vanuit het perspectief van de werknemer beïnvloeden deze selectiepatronen de carrièrekeuzes en mogelijk ook de beroepskeuze en de investeringen in menselijk kapitaal. Bovendien leiden discrepanties tussen daadwerkelijke en de geprefereerde incentives tot meer werkstress. Dit is bijvoorbeeld het geval wanneer zittende werknemers geconfronteerd worden met een verandering in hun beloningsregeling. Werkstress brengt op zijn beurt weer risico's voor de mentale en psychologische gezondheid en het welzijn van de werknemers met zich mee. 


\section{Tabel 1}

Selectie in de arbeidsmarkt

(1)

(2)

(3)

Alleen private sector

\begin{tabular}{|c|c|c|c|}
\hline Afhankelijke variabele & $\begin{array}{l}1 \text { als publieke } \\
\text { sector }\end{array}$ & $\begin{array}{l}1 \text { als } \\
\text { prestatieloon }\end{array}$ & $\begin{array}{l}1 \text { als } \\
\text { prestatieloon }\end{array}$ \\
\hline \multirow[t]{2}{*}{ Risicohouding } & $-0.004^{*}$ & $0.008^{* * *}$ & $0.006^{* *}$ \\
\hline & {$[0.002]$} & {$[0.003]$} & {$[0.003]$} \\
\hline \multirow[t]{2}{*}{1 als vrouw } & $0.03^{* * *}$ & $-0.070^{* * *}$ & $-0.051^{* * *}$ \\
\hline & {$[0.011]$} & {$[0.014]$} & {$[0.015]$} \\
\hline \multirow[t]{2}{*}{ Aantal jaren onderwijs } & $0.007^{* * *}$ & $0.034^{* * *}$ & $0.009^{* * *}$ \\
\hline & {$[0.002]$} & {$[0.003]$} & {$[0.003]$} \\
\hline Controle variabelen voor ervaring & ja & ja & ja \\
\hline $\begin{array}{l}\text { Controle variabelen voor } \\
\text { leeftijd en aanstellingsduur }\end{array}$ & nee & ja & ja \\
\hline $\begin{array}{l}\text { Controle variabelen voor } \\
\text { vertrouwen en reciprociteit }\end{array}$ & ja & ja & ja \\
\hline $\begin{array}{l}\text { Controle variabelen voor } \\
\text { bedrijfsgrootte en sector }\end{array}$ & ja & nee & ja \\
\hline $\begin{array}{l}\text { Controle variabelen voor } \\
\text { beroepsgroep }\end{array}$ & nee & nee & ja \\
\hline Observaties & 8097 & 5184 & 5184 \\
\hline Pseudo R-squared & 0.440 & 0.0689 & 0.200 \\
\hline
\end{tabular}

Noot: De tabel toont de marginale effecten, op basis van de gemiddelde waardes van de verklarende variabelen, van probitmodellen. Robuuste standaardfouten staan tussen haakjes, * significant op 10\%; ${ }^{* *} 5 \% ;{ }^{* * *} 1 \%$. De afhankelijke variabele in kolom (1) heeft de waarde 1 als de respondent in de publieke sector werkt en o indien de respondent in een andere sector werkt. De steekproef in kolom (1) bestaat alleen uit werkende personen jonger dan 65, die momenteel niet ingeschreven staan bij een onderwijsinstelling. Observaties waarbij informatie voor verklarende variabelen ontbreekt worden niet meegenomen. De afhankelijke variabele in kolom (2) en (3) heeft de waarde 1 als de prestatie van de respondent beoordeeld wordt. Voor kolom (2) en (3) gelden dezelfde steekproefrestricties als voor kolom (1). Bovendien zijn werknemers uit de publieke sector hier niet meegenomen. Met uitzondering van de meting van vertrouwen en reciprociteit, die afkomstig zijn uit respectievelijk cohort 2003 en 2005, zijn de data afkomstig uit de $2004 \mathrm{co}$ hort van de Duitse Socio-Economische Panel studie. Positieve reciprociteit wordt gemeten door de gemiddelde score van de mate van instemming met drie beweringen: (1) de bereidheid iets terug te doen na een gunst, (2) de mate waarin iemand het ontloopt om iemand te helpen die op een eerder moment aardig was en (3) de mate waarin iemand bereid is persoonlijke kosten te maken om iemand te helpen die jou eerder geholpen heeft. Negatieve reciprociteit wordt hier gemeten 
door de gemiddelde score van de mate van instemming met beweringen over de bereidheid (1) om wraak te nemen na een ernstige fout, (2) om zich te wreken, na in een moeilijke positie te zijn gebracht en (3) iemand te beledigen, na eerder zelf beledigd te zijn. Antwoorden zijn steeds op een schaal van 1 tot 7, waarbij 1 betekent "dit is totaal niet op mij van toepassing" en 7 betekent " is helemaal op mij van toepassing". De maatstaf van vertrouwen is de gestandaardiseerde principale component van de mate van overeenstemming van de respondent met betrekking tot drie verschillende beweringen over de betrouwbaarheid van anderen (gemeten op een vierpunts-schaal variërend van "volledig eens" tot "volledig oneens") welke zijn opgenomen in de cohort van 2003. De meting is verkregen door het uitvoeren van een principale componentenanalyse op de eerder beschreven steekproef.

\section{Consequenties van een verandering in de incentive-structuur}

Om de productiviteit in de publieke sector te vergroten, wordt regelmatig voorgesteld om hier net als in het bedrijfsleven een variabel beloningssysteem in te voeren. Maar wat zouden de gevolgen zijn van een dergelijke verandering? Neem het voorbeeld van docenten. In Duitsland en Nederland zijn docenten voornamelijk werkzaam in de publieke sector, waarin ze te maken hebben met een systeem van vaste salarissen. Het risico om door ontslag werkloos te worden is vrij klein.

Wie wordt er nu docent? Tabel 2 laat het zien. Ik vergelijk alleen mensen met een 'Abitur' omdat dat opleidingsniveau nodig is om docent te worden in Duitsland. Vrouwen hebben ongeveer 13 procent meer kans om docent te worden dan mannen. Er is opnieuw een significant negatieve correlatie tussen de mate waarin iemand bereid is om risico's te nemen en de kans om het docentenvak te kiezen. In de huidige incentive-structuur hebben mensen, die er niet van houden risico's te nemen, een veel grotere kans om docent te worden. De coëfficiënt geeft aan dat voor elk punt op de 11-punts schaal die wordt gehanteerd in de vragenlijst, de kans om docent te worden, met bijna twee procentpunten afneemt. Er zijn ook significante effecten van sociale voorkeuren: docenten zijn significant minder negatief reciproque in vergelijking met de controle groep. Ook de persoonlijkheid van docenten blijkt af te wijken van het gemiddelde. Docenten zijn zorgvuldiger, meer altruïstisch en staan meer open voor nieuwe ervaringen dan anderen. ${ }^{10}$ doorzettingsvermogen, motivatie, regulering van motivatie, etc. (zie Borghans c.s., 2008). De 2005-golf 


\section{Tabel 2}

\section{Selectie van docenten in het docentenvak}

\begin{tabular}{lll}
\hline & $(1)$ & $(2)$ \\
& Duitsland & Nederland \\
\hline Risicohouding & & \\
& $-0.014^{* * *}$ & $-0.034^{* * *}$ \\
1 als vrouw & {$[0.005]$} & {$[0.012]$} \\
& $0.132^{* * *}$ & $0.248^{* * *}$ \\
Leeftijd (in jaren) & {$[0.021]$} & {$[0.047]$} \\
& $0.011^{* * *}$ & $0.023^{* * *}$ \\
Positieve reciprociteit & {$[0.001]$} & {$[0.003]$} \\
& -0.005 & 0.022 \\
Negatieve reciprociteit & {$[0.011]$} & {$[0.029]$} \\
& $-0.027^{* * *}$ & $-0.040^{*}$ \\
\hline Observaties & {$[0.008]$} & {$[0.021]$} \\
Pseudo R-squared & 1521 & 353 \\
\hline
\end{tabular}

Noot: De tabel toont de marginale effecten, op basis van de gemiddelde waardes van de verklarende variabelen, van probitmodellen. Standaardfouten staan tussen haakjes, ${ }^{*}$ significant op $10 \% ;{ }^{* *} 5 \% ;{ }^{* * *} 1 \%$. De afhankelijke variabele in kolom (1) heeft waarde 1 als de respondent een docent is in Duitsland (inclusief elke vorm van onderwijsberoepen en schoolhoofden) en o indien anders. Met uitzondering van de onderzoeksvragen over reciprociteit, die afkomstig zijn uit de cohort van 2005, zijn de data afkomstig van de cohort van 2004 uit het Duitse Socio-Economische Panel. In de steekproef worden alleen werkende personen meegenomen die jonger zijn dan 65, die momenteel niet in ingeschreven staan in een onderwijsinstelling en die een vooropleiding hebben die hen toelaat om universitair onderwijs te volgen. De afhankelijke variabele in kolom (2) heeft de waarde 1 als de respondent heeft gekozen voor een lerarenopleiding in Nederland. De data zijn afkomstig van ROA's schoolverlatersonderzoek 2009. In deze steekproef worden alleen $\mathrm{HBO}$-studenten meegenomen. Risicohouding wordt in beide steekproeven gemeten met het antwoord op de algemene risicovraag. Positieve reciprociteit wordt gemeten door de gemiddelde score van de mate van instemming met drie beweringen: (1) de bereidheid iets terug te doen na een gunst, (2) de mate waarin iemand het ontloopt om iemand te helpen die op een eerder moment aardig was en (3) de mate waarin iemand bereid is persoonlijke kosten te maken om

van de SOEP bevat een korte versie van de Big Five, bestaande uit 15 items, 3 voor elke factor (zie Gerlitz en Schupp (2005) voor meer details). Respondenten hebben verschillende stellingen voorgelegd gekregen en hebben vervolgens op een 7 puntsschaal kunnen weergeven in hoeverre deze stellingen op hen van toepassing zijn. 
iemand te helpen die jou eerder geholpen heeft. Negatieve reciprociteit wordt hier gemeten door de gemiddelde score van de mate van instemming met beweringen over de bereidheid (1) om wraak te nemen na een ernstige fout, (2) om zich te wreken, na in een moeilijke positie te zijn gebracht en (3) iemand te beledigen, na eerder zelf beledigd te zijn. Antwoorden zijn steeds op een schaal van 1 tot 7, waarbij 1 betekent "dit is totaal niet op mij van toepassing" en 7 betekent "is helemaal op mij van toepassing".

Misschien vraagt $u$ zich af of deze bevindingen ook voor Nederland van toepassing zijn. Om deze vraag te beantwoorden heb ik data gebruikt van het schoolverlatersonderzoek dat elk jaar in Nederland wordt uitgevoerd door het ROA. De tabel laat zien dat Nederlandse HBO'ers die bereid zijn om meer risico te nemen, minder kans hebben om docent te worden. ${ }^{11}$ Daarnaast zijn net zoals in Duitsland vrouwen en mensen met een lage negatieve reciprociteit vaker docent.

Hoewel docenten in alle sectoren van het onderwijs te maken hebben met vergelijkbare incentive-structuren zijn er ook opvallende verschillen. Ten eerste is, niet geheel onverwacht, het man-vrouw-verschil anders voor docenten aan de universiteit of hogeschool dan voor basisschoolleraren. Terwijl de basisschoolleraren significant vaker vrouw zijn, zijn de docenten aan hogescholen en universiteiten vaker mannen. In termen van risico, valt het op dat docenten aan de middelbare school minder risico-avers zijn dan basisschoolleraren. Dit kan verklaard worden doordat de middelbare school meer promotiemogelijkheden kent dan de basisschool. ${ }^{12}$ Ook qua persoonlijkheid zijn er verschillen. Professoren aan de universiteit zijn bijvoorbeeld meer open voor nieuwe ervaringen. Dit laat een analyse op basis van de SOEP data zien (zie Dohmen en Falk, 2010b). ${ }^{13}$

Samengevat, zijn er systematische verschillen te zien tussen docenten en mensen die docent hadden kunnen worden, maar gekozen hebben om dat niet te doen. Deze selectie-effecten zijn belangrijk wanneer we de

11 Ik heb mij beperkt tot het schoolverlatersonderzoek onder HBO'ers, omdat in Nederland een HBO opleiding vereist is voordat men mag doceren. In 2009 hebben we de respondenten van de HBO Monitor gevraagd een additionele vragenlijst over voorkeuren, gedrag en persoonlijkheidskenmerken in te vullen. Onder de 353 respondenten die volledige informatie over risicohouding en reciprociteit geven vallen 99 docenten.

12 Docenten aan de middelbare school in Duitsland hebben beperkte promotiemogelijkheden, terwijl basisschoolleraren die vrijwel niet hebben(zie Wößmann, 2008).

13 Dohmen en Falk (2010b) schatten een multinominaal logitmodel om te bekijken hoe verschillen in incentives en baanprofielen onder docenten verschillende selectiepatronen teweeg kunnen brengen. De afhankelijke variabele in hun model maakt onderscheid tussen 5 categorieën voor verschillende groepen van docenten: basisschool docent, docent aan een Duitse Hauptschule/Realschule, middelbare school docent (Gymnasium, Gesamtschule, Berufsschule), docent aan het hoger beroepsonderwijs en de universiteit, en andere onderwijsberoepen (zie tabel 4 in Dohmen en Falk, 2010b). 
consequenties van het introduceren van financiële prikkels voor werknemers in de onderwijssector overdenken. Hiervoor zijn drie redenen te noemen: Ten eerste, creëren veranderingen in incentive-systemen mogelijk spanningen en ontevredenheid. De reden hiervoor volgt direct uit het feit dat werknemers in de onderwijssector, de docenten, zichzelf op basis van hun voorkeuren hebben geselecteerd voor een functie waarin inkomen gebaseerd is op een vaste beloning. Deze mensen zouden dan ineens geconfronteerd worden met een betalingssysteem waarin hun loon afhankelijk wordt gemaakt van output en prestatie. Als hun selectiebeslissing in eerste instantie optimaal was, dan zal de nieuwe beloningssystematiek tot ontevredenheid leiden. Met andere woorden: voor een gegeven salaris zal de baantevredenheid van docenten dan dalen. Dit effect zal voortduren tot er een nieuw geselecteerde generatie docenten aan het werk zal zijn. De afname in tevredenheid c.q. nut zou kunnen leiden tot weerstand tegen hervormingen, die trachten om de beloning meer te laten afhangen van prestaties. Dit kan mogelijk leiden tot conflicten, verminderde inspanningen en een lagere kwaliteit van de output van docenten of dit zal gecompenseerd moeten worden met een hoger salaris.

Ten tweede, en gerelateerd aan het eerste punt, zou het inefficiënt kunnen zijn om incentives te versterken als docenten inderdaad risicomijdend blijken te zijn. Een bekend inzicht van de incentive theorie is het bestaan van een trade-off tussen risico's en incentives. De intuïtie hierachter is dat incentives agenten blootstellen aan risico's, waarvoor ze gecompenseerd moeten worden. ${ }^{14}$ Dus als docenten relatief risico-avers zijn, is voor deze groep dus een hoge compensatie nodig voor het risico dat variabele beloning met zich meebrengt.

Ten derde kunnen andere voorkeuren, gedrag en persoonlijkheidskenmerken een rol spelen in het selectieproces. Zo heb ik laten zien dat docenten relatief veel vertrouwen hebben in anderen en een weinig negatief reciproque gedrag vertonen. Het is te verwachten dat de introductie van een variabel betalingssysteem in de onderwijssector zal leiden tot het aantrekken van docenten die minder vertrouwen hebben in anderen en meer negatief reciproque zijn ten koste van het huidige docentenprofiel. We kunnen alleen maar speculeren over de veranderingen die de samenstelling van het docentencorps zou kunnen hebben voor de kwaliteit van het onderwijs. Docenten hebben bijvoorbeeld belangrijke voorbeeldfuncties voor studenten en beïnvloeden de gedragsvorming van hun studenten. Er zijn bijvoorbeeld aanwijzingen dat sociale voorkeuren zoals 
vertrouwen gedeeltelijk gevormd worden door omgevingsfactoren (Dohmen c.S., 2006).

Aan de andere kant zou de invoering van variabele beloningsregelingen een gunstige uitwerking kunnen hebben op andere kenmerken van docenten. Het is niet gemakkelijk om de balans op te maken, maar wat we met zekerheid kunnen zeggen is dat veranderingen in de beloningsstructuur zullen leiden tot grote veranderingen in de samenstelling van het docentencorps. Dit effect moet worden meegenomen bij beslissingen over de introductie van incentives in het onderwijs.

\section{Beleidsimplicaties}

\section{Implicaties voor de samenstelling van werknemers in bedrijven en sectoren}

Selectie op basis van voorkeuren in incentive-systemen heeft belangrijke beleidsimplicaties, omdat de manier waarop werknemers problemen aanpakken en taken afronden afhangt van hun voorkeuren, gedrag en persoonlijkheid. Er zijn banen zoals veiligheidsofficieren waarvoor het belangrijk is dat werknemers geen overbodige risico's nemen. Om ervoor te zorgen dat risico-averse mensen aangetrokken worden voor dergelijke banen, zou variabele beloning negatief uit kunnen pakken. Als beloningsregelingen in bepaalde sectoren mensen aantrekken die graag risico's nemen, moeten we niet verbaasd zijn als de werknemers in deze sectoren daadwerkelijk overmatige risico's nemen. Met dit in het achterhoofd kunnen we ons afvragen in hoeverre belonings regelingen in het investeringsbankwezen de "verkeerde" mensen hebben aangetrokken. In andere banen zou risicotolerantie voordelen kunnen hebben, waardoor daar variabele beloning echt nuttiger zou zijn. Omdat werknemers met verschillende voorkeuren duidelijk gekozen hebben voor banen met bepaalde incentivesystemen, zal de introductie van een nieuwe beloningsstructuur niet in alle bedrijven eenzelfde reactie teweegbrengen. Dit is een belangrijke conclusie. Voordat bedrijven hervormingen implementeren die ergens anders succesvol bleken, moeten zij kritisch nagaan of dezelfde positieve effecten te verwachten zijn bij de werknemers die al werkzaam zijn binnen het bedrijf. Als dit niet te verwachten valt, zal er tijd verstrijken voordat het volledige effect van de hervormingen zichtbaar wordt, namelijk tot de 'huidige' werknemers vertrokken zijn en er een andere groep werknemers is aangetrokken. Als bijvoorbeeld de overheid overweegt om variabele beloningsregelingen te introduceren in de publieke sector, doet ze er goed aan er rekening mee te houden dat de samenstelling van het per- 
soneel in de publieke sector op een voorspelbare manier zal veranderen. Een dergelijke verandering kan nadelen hebben, maar kan ook juist zeer wenselijk zijn. Verandering is dan wel een kwestie van een lange adem.

\section{Disfunctionele effecten van geforceerde incentive-systemen}

Buiten het directe effect op de samenstelling van het personeelsbestand, biedt selectie op basis van voorkeuren ook een verklaring voor andere fenomenen. Voorbeelden hiervan zijn vragen als 'waarom is er een wijdverbreide weerstand tegen veranderingen in beloningsregelingen onder het zittend personeel?' en 'waarom zijn financiële prikkels schadelijk voor sommige type werknemers maar niet voor anderen?'.

Indien werknemers juist kiezen voor een bepaald bedrijf te gaan werken, omdat zij het incentive-systeem van dat bedrijf prefereren boven het incentive-systeem van een ander bedrijf, dan valt te verwachten dat zij weerstand zullen bieden tegen een verandering in de beloningsregelingen. Het veranderen van de incentives kan daarom schadelijke consequenties hebben voor de organisatie. Het kan ertoe leiden dat veel personeel vertrekt en het kan betekenen dat de incentives niet tot een verhoging van de productiviteit leiden. Zo zullen de productiviteitseffecten van variabele beloningsregelingen waarschijnlijk sterker zijn voor werknemers die bewust hebben gekozen voor een baan met dit soort beloningsregelingen dan voor werknemers die daartoe gedwongen worden. Bovendien is de kans op verhoogde werkstress veel groter als er van mensen wordt geëist om in een bepaald incentive-structuur te werken. Zo zullen werknemers, die de voorkeur geven aan werk tegen een vast salaris, meer last hebben van de onzekerheid die het incentivesysteem met variabele beloning met zich meebrengt. Inkomensonzekerheid, concurrentie, loonongelijkheid, de dreiging van mislukking op het werk, en baanonzekerheid zijn grote bronnen van stress op het werk (Moutsatsos, 2008). Toen mensen in ons laboratoriumexperiment opgelegd kregen onder een variabel beloningssysteem te werken, was de zelfgerapporteerde werkstress veel hoger dan bij degenen die wel voor zo'n incentive-systeem hadden gekozen. Omdat psychische stress op het werk negatieve emoties oproept (Weiner, 1992), en omdat aanhoudende stress de fysieke en mentale gezondheid op de lange termijn negatief beïnvloedt, is het voor bedrijven ook gewenst om beloningssystemen te ontwikkelen die langdurige negatieve gezondheidseffecten tegengaan. 


\section{Effecten naar geslacht}

De man-vrouw-verschillen in voorkeuren hebben ook belangrijke beleidsimplicaties. Naast de voor-de-hand-liggende implicaties voor de verschillen in de beroepskeuze van mannen en vrouwen en de beloningsverschillen, kunnen verschillen in voorkeuren mede verklaren waarom het welzijn van vrouwen de laatste vier decennia minder is toegenomen dan het welzijn van mannen. Hoewel gedurende deze periode de sociaal-economische condities voor vrouwen meer zijn verbeterd dan voor mannen, blijkt uit meerdere survey's dat hun welzijn daalt in vergelijking met dat van mannen (Stevenson and Wolfers, 2009). Resultaten van ons onderzoek doen vermoeden dat vrouwen meer geleden hebben onder de toename van het gebruik van variabele beloningsystemen dan mannen. Omdat vrouwelijke deelnemers onder het variabele beloningssysteem in het lab hogere niveaus van stress rapporteren dan mannen, is het te verwachten dat vrouwen de toename in werk- en beloningsonzekerheid als meer belastend hebben ervaren.

\section{Implicaties van de vergrijzing}

Selectie op basis van voorkeuren heeft ook implicaties in een vergrijzende samenleving. Als werknemers naarmate ze ouder worden minder bereid zijn om risico's te nemen, dan zullen zij een sterkere voorkeur ontwikkelen voor baanstabiliteit en zullen zij inkomensonzekerheid proberen te vermijden. Het kan daarom verwacht worden dat werknemers aan het eind van hun loopbaan op zoek gaan naar banen met minder variabele beloningsregelingen. De vraag naar baanstabiliteit en afname in inkomensonzekerheid zal daarom toenemen in landen die kampen met vergrijzing. De kosten van variabele beloningssystemen zullen daarom toenemen. Deze kosten komen in twee vormen: (1) bedrijven moeten een hogere risicopremie betalen wanneer ze variabele beloningsregelingen aanbieden, en (2) disfunctionele effecten van variabele beloningsregelingen, zoals een toenemende stress, zullen sterker worden.

\section{Implicaties voor het financieren van onderwijs}

Als mensen die verschillen in economische voorkeuren beroepen selecteren die daarbij passen, is het te verwachten dat zij ook verschillende opleidingsinvesteringen doen en dat zij zich voor verschillende studierichtingen zullen inschrijven. Dit heeft implicaties voor het veranderen van de incentives in het onderwijssysteem. Een toename in het collegegeld en een reductie van de studiebeurs zal bijvoorbeeld niet alleen leiden tot een afname van het aantal studenten, omdat voor sommige studenten de private 
opbrengsten van het onderwijs niet zullen volstaan om de toegenomen kosten te dekken, maar een verhoging van het collegegeld zal bovendien leiden tot een verandering in de samenstelling van de studentenpopulatie. Over het algemeen geldt dat de kans, dat leerlingen na het behalen van hun middelbare-schooldiploma niet gaan studeren, het grootste is onder degenen die het meest risico-avers zijn. Dit komt doordat voor deze risico averse leerlingen de verwachte opbrengsten hoger moeten zijn om nog voldoende compensatie voor het risico te bieden. Omdat vrouwen en ook mensen uit een lager sociaal-economisch milieu gemiddeld meer risicoavers zijn, kan men verwachten dat bij een verhoging van het collegegeld de inschrijvingspercentages onder deze groepen het meest zullen dalen. Het verschil in de samenstelling van studenten zal ook terug te zien zijn in de verdeling over studierichtingen. Neem de inschrijving voor een studie die opleidt tot docent als voorbeeld. Studenten die docent willen worden, zijn over het algemeen minder bereid risico's te nemen dan anderen. Minder financiële steun voor studenten zal daarom met name leiden tot een afname van het aantal studenten in de docentenopleidingen.

\section{Implicaties voor sociale mobiliteit}

Ten slottekan het relaterenvan carrièrekeuzes aan risico-,tijds-en socialevoorkeuren leiden tot nieuwe ideeën voor het sociale beleid. Zo heeft de loopbaankeuze op basis van deze voorkeuren ook gevolgen voor het overheidsbeleid dat sociale mobiliteit stimuleert en inkomensongelijkheid tracht te verkleinen. Als voorkeuren van ouders op kinderen worden overgedragen, dan hebben kinderen vergelijkbare voorkeuren als hun ouders en zijn ze daarom geneigd soortgelijke carrièrekeuzes te maken als hun ouders. Daardoorworden zij met dezelfdegevolgen geconfronteerd. Deoverdraagbaarheid van voorkeuren zal daarom de intergenerationele sociaal-economische immobiliteit versterken. Sociale mobiliteit wordt dus niet alleen belemmerd, omdat kinderen uit zwakke sociaal-economische milieus financiële beperkingen hebben om in hun opleiding te investeren, minder gunstige sociale netwerken hebben en mogelijk ook een informatieachterstandhebben. Hetverminderenvandezebelemmeringen is ongetwijfeld van belang om sociale ongelijkheid te verminderen. Maar het is ook belangrijk om te beseffen dat het succes van dit beleid begrensd is. 


\section{Dankwoorden}

Mijnheer de rector, dames en heren, ik heb mij jaren geleden op weg begeven. Op mijn reis ben ik velen tegengekomen, die mij geholpen hebben aan deze bestemming te komen. Sommige hebben mij de richting gewezen, enige hebben mij onderweg aangemoedigd, enkele hebben mij daarin begeleid. Daarvoor ben ik hen zeer dankbaar. Daarom wil ik mijn woorden van dank uitspreken.

Ik bedank de rector professor Mols en het College van Bestuur van de Universiteit Maastricht, de decaan van de School of Business and Economics, professor Lemmink, de sectievoorzitter professor Muysken, en de benoemingscommissie voor het vertrouwen dat $u$ in mij heeft gesteld. Ik ben zeer dankbaar dat u mij in de gelegenheid stelt om hier in Maastricht mijn onderzoek uit te voeren. De combinatie van de leerstoel met het directeurschap van het Researchcentrum voor onderwijs en arbeidsmarkt (ROA) is fantastisch. Deze combinatie stelt mij, stelt ons, in de gelegenheid de brug te slaan tussen de wereld buiten de universiteit en de wetenschap. Bovendien bieden de contacten met de beleidswereld een bron van inspiratie voor mijn academisch onderzoek.

Dank ben ik ook verschuldigd aan professor Hans Heijke, die mij mijn instap bij het ROA zo gemakkelijk maakte. Het ROA is meer dan alleen maar een onderzoeksinstituut. Het is een gemotiveerd team van mensen dat de waarde van het ROA uitmaakt. Ik ben trots en dankbaar dat ik met jullie samen kan werken. Ik heb bewondering en waardering voor de stroom van ideeën en de onderzoeksomgeving die mijn collega's van het ROA, de vakgroep AE2 en van de School of Business and Economics hier in Maastricht creëren. Ik ben dankbaar dat ik ook in het verleden van inspirerende samenwerk-ingsverbanden kon genieten. Vele inzichten die ik in deze rede presenteerde, vloeien voort uit onderzoeken die ik met een aantal collega's bij het Institut zur Zukunft der Arbeit (IZA) in Bonn uitvoerde, vooral met Armin Falk, David Huffman en Uwe Sunde.

De grondsteen voor mijn academische carrière als econoom werd hier in Maastricht gelegd, waar ik zeer veel leerde van mijn promotoren professor Gerard Pfann en professor Franz Palm. Daarvoor dank. Graag denk ik ook terug aan de BIRC-tijden en mijn toenmalige collega's. Veel van hen zijn nog steeds werkzaam bij de Universiteit Maastricht. Ben Kriechel, die mij ooit op de toen nieuwe doctoraalopleiding International Economic Studies in Maastricht attent maakte, en mij vier jaar later op een oio-project bij BIRC heeft gewezen, werkt zelf bij het ROA. 
Maar, en nu vervolg ik in het Duits.

Aber jetzt liebe Familie werde ich etwas auf Deutsch sagen.

Liebe Familie, der größte Dank gilt Euch. Dass ich hier heute stehe, verdanke ich besonders Dir, liebe Verena, Dir, liebe Mutter, und unserem lieben Vater, der sich heute so gefreut hätte.

Mijnheer de rector, dames, heren,

Ik heb gezegd. 


\section{Literatuur}

Andersen, Steffen, Glenn W. Harrison, Morten I. Lau, Elisabet Rutstrom (2008). Eliciting Risk and Time Preferences. Econometrica 76(3): 583-618. Becker, Gary. (1975). Human Capital. New York: Columbia University Press.

Ben-Porath, Yoram. (1967). 'The Production of Human Capital and the Life Cycle Earnings.' Journal of Political Economy, vol. 75, pp. 352-65.

Bonin, Holger, Thomas Dohmen, Armin Falk, David Huffman, Uwe Sunde (2007). Cross-Sectional Earnings Risk and Occupational Sorting: The Role of Risk Attitudes. Labour Economics 14(6): 926-937.

Borghans, Lex, Angela Lee Duckworth, James J. Heckman, Bas ter Weel (2008). The Economics and Psychology of Personality Traits. Journal of Human Resources 43(4): 972-1059.

Brown, Martin, Falk, Armin, Ernst Fehr (2004). Relational Contracts and the Nature of Market Interactions. Econometrica 72: 747-780.

Caliendo, Marco, Frank M. Fossen, Alexander S. Kritikos (2009). Risk Attitudes of Nascent Entrepreneurs:NewEvidence from an Experimentally Validated Survey. Small Business Economics 32(2):153-167.

Cramer, Jan S., Joop Hartog, Nicole Jonker, C. Mirjam van Praag (2002). Low Risk Aversion Encourages the Choice for Entrepreneurship: An Empirical Test of a Truism. Journal of Economic Behavior \& Organization 48 (1): $29-36$.

DeLeire, Thomas and Helen Levy (2004). Worker Sorting and the Risk of Death on the Job. Journal of Labor Economics 19(4): 837-878.

Dohmen, Thomas and Armin Falk (2010a). Performance Pay and Multidimensional Sorting: Productivity, Preferences and Gender. American Economic Review forthcoming.

Dohmen, Thomas and Armin Falk (2010b). You Get What You Pay for: Incentives and Selection in the Education System. Economic Journal forthcoming. 
Dohmen, Thomas, Armin Falk, David Huffman, Uwe Sunde (2006). The Intergenerational Transmission of Risk and Trust Attitudes. IZA Discussion Paper 2380.

Dohmen, Thomas, Armin Falk, David Huffman, Uwe Sunde (2008). Representative Trust and Reciprocity: Prevalence and Determinants. Economic Inquiry 46(1): 84-90.

Dohmen, Thomas, Armin Falk, David Huffman, Uwe Sunde (2009). Homo Reciprocans: Survey Evidence on Behavioral Outcomes. Economic Journal 119: 592-612.

Dohmen, Thomas, Armin Falk, David Huffman, Uwe Sunde, Jürgen Schupp, Gert G. Wagner (2010a). Individual Risk Attitudes: Measurement, Determinants and Behavioral Consequences. Journal of the European Economic Association forthcoming.

Dohmen, Thomas, Armin Falk, David Huffman, Uwe Sunde (2010b). Are Risk Aversion and Impatience Related to Cognitive Ability? American Economic Review forthcoming.

Ekelund, Jesper, Edvard Johansson, Marjo-Riitta Järvelin, Dirk Lichtermann (2005). Self-Employment and Risk Aversion — Evidence from Psychological Test Data. Labour Economics 12(5): 649-659.

Fehr, Ernst, Georg Kirchsteiger, Arno Riedl (1993). Does Fairness Prevent Market Clearing? An Experimental Investigation. Quarterly Journal of Economics 108: 437-460.

Frederick, Shane, George Loewenstein, Ted O'Donoghue (2002). Time Discounting and Time Preference: A Critical Review, Journal of Economic Literature, 40: 351-401.

Gerlitz, Jean-Yves and Jürgen Schupp (2005). Zur Erhebung der Big-Fivebasierten Persönlichkeitsmerkmale im SOEP. DIW Research Notes 4.

Glaeser, Edward L., David I. Laibson, J. A. Scheinkman, and C. Soutter (2000): Measuring Trust, Quarterly Journal of Economics 115(3): 811-846. 
Guiso, Luigi, Tullio Japelli, Luigi Pistaferri (2002). An Empirical Analysis of Earnings and Employment Risk. Journal of Business \& Economic Statistics 20(2): 241-253.

Jaeger, David, Thomas Dohmen, Armin Falk, David Huffman, Uwe Sunde, Holger Bonin (2010). Direct Evidence on Risk Attitudes and Migration. Review of Economics and Statistics forthcoming.

Kosfeld, Michael, M. Heinrichs, P. Zak, Urs Fischbacher, Ernst Fehr (2005): Oxcytocin Increases Trust in Humans. Nature 435(2): 673-676.

Levhari, David. and Yoram Weiss (1974). The Effect of Risk on the Investment in Human Capital. American Economic Review. 64(6): 950-63.

Mincer, Jacob (1958). Investment in Human Capital and the Personal Income Distribution. Journal of Political Economy 66: 281-302.

Mincer, Jacob (1974). Schooling Experience and Earnings. New York: Columbia University Press.

Starmer, Chris (2000). Developments in Non-Expected Utility Theory: The Hunt for a Descriptive Theory of Choice under Risk. Journal of Economic Literature 38: 332-382.

von Neumann, John \& Oskar Morgenstern (1944). Theory of Games and Economic Behavior. Princeton University Press, Princeton NJ.

Wößmann, Ludger (2008). Entering the Teacher Workforce in Germany. Report to the Urban Institute in association with its work with the Gates Foundation on the development of human capital in education, University of Munich. 